\title{
Mathematical evaluation of chromosomal anomalies induced by xylol in Vicia faba L. regarding application time and concentration
}

\author{
Ali Özdemir ${ }^{1}$ and Canan Özdemir ${ }^{2, *}$ \\ ${ }^{1}$ Celal Bayar University, Science and Art Faculty, Mathematics Department, Manisa, Turkey; ${ }^{2}$ Celal Bayar University, Science and Art \\ Faculty, Biology Department, Manisa, Turkey.
}

Received: June 12, 2021; Revised: August 4, 2021; Accepted: September 4, 2021

\begin{abstract}
Abstact
This study investigates how xylol acts on chromosomes of broad bean (Vicia faba L.) according to the time and concentration parameters. Xylol has the chemical formula $\mathrm{C}_{6} \mathrm{H}_{4}\left(\mathrm{CH}_{3}\right)_{2}$, which is also called dimethylbenzene. This chemical is evaluated as a basic substance or a supplementary basic substance in many industrial products such as farming chemicals. Xylol is used as a typical solvent in solvent-based formulations and serves as the carrier solution for the pesticide ingredient in farming chemicals.

The present study investigates the chromosomal changes induced by xylol in the meristematic cells of the root tips of $V$. faba, which is widely used as food by humans. The root tips were treated with xylol solutions which are prepared in various concentrations (5,20,40 and $80 \mathrm{ml} / \mathrm{L}$ ) for different treatment duration periods (8 and $72 \mathrm{~h}$ ). The aim of the microscopic examination was to clarify chromosomal anomalies of cell division. The microscopic examination showed that various anomalies occurred in cells of the root tip meristems such as chromosome breaking, dispersion, adherence, bridge chromosome and ring chromosomes. The data obtained from microscopic analysis in the study were evaluated statistically. We have tried to demonstrate and assess the effects obtained from laboratory studies numerically. The Pearson's correlation and variance analysis were applied to data to reveal the similarities and the differences of the chromosomal features. The statistical analyses used in the study also serve the purpose of reliability, concreteness and the comparison of the results. The study also sheds light on the possible harms of xylol on chromosomes transferring genetic codes of living beings to forthcoming generations.
\end{abstract}

Keywords: Chromosome Anomalies, Mathematically Evaluation, Xylol, Vicia faba.

\section{Introduction}

Xylol is uncoloured, characteristical dissolvent, fragrant and fluid form crude substance with a chemical formula of $\mathrm{C}_{6} \mathrm{H}_{4}\left(\mathrm{CH}_{3}\right)_{2}$. It was first isolated and named in 1850 by the French chemist Auguste Cahours, having been discovered as a constituent of wood tar (Cahours, 1850). It has industrial value and medical technology as a solvent, but concerns about its safety have raised questioned from time to time. In addition, the areas of application of xylol include the printing, rubber, and leather industries. It can be used where slower drying is desired (Jenifer, 1994). For similar reasons, it is often the active ingredient in commercial products for ear wax removal (Fabri et al., 2000). Xylol easily penetrates most ordinary clothing and can become trapped in ordinary gloves and boots. Xylol trapped in the clothing can cause burns and blistering. Long-term exposure to xylol may lead to headaches, irritability, depression, insomnia, agitation, extreme tiredness, tremors, impaired concentration and short-term memory loss. This condition is sometimes generally referred to as "organic solvent syndrome." Unfortunately, there is very little information available that isolates xylol from other solvent exposures in the examination of these effects. The type and severity of health effects depends on several factors, including the amount of xylol you are exposed to and the exposure time (Vijayakumar, 2015). In the literature, some researchers made investigations on cytogenetic effects of especially heavy metal pollution on plants and other living things (Shraideh, 2010; Özdemir et al., 2015; Şutan et al., 2018; Osama et al., 2020; Tengjaroenkul \& Neeratanaphan, 2020). In the literature, the studies on the effects of solvents on plants have mostly been evaluated in terms of agricultural productivity (Barchan et al., 2014; Ghasemzadeh et al., 2011). Studies on the effects of solvents on plant chromosomes are very limited. Recently, Alaca et al., (2020) have investigated the effect of xylol solvent on Vicia faba plant chromosomes for different concentration and time.

In this study, we investigated the effects of xylol used as raw materials in many industrial products especially agrochemicals on the $V$. faba plant as a model system for plant cytogenetic studies to configure its mode of action on mitotic chromosomes

The new aspect here is to evaluate the data observed from the research mathematically, in particular

\footnotetext{
* Corresponding author e-mail: cozdemir13@gmail.com.
} 
statistically. Statistical analysis was performed using Pearson's correlation and analysis of variance methods, which are widely used in similar studies.

\section{Material and Methods}

The study was carried out in Manisa Celal Bayar University, Botanical Research Laboratory in 2020. Ten number plump and equal-sized seeds of $V$. faba were used for each treatment and as a control group. The seeds were soaked with distilled water for $10-15$ minutes then germinated at $20-25^{\circ} \mathrm{C}$ in petri dish. When the root tips reached $10-15 \mathrm{~mm}$ in length, germinated seeds were treated with different concentrations $(5,20,40$ and $80 \mathrm{ml} / \mathrm{L})$ of xylol for 8 and 72 hours. The root tips of the control group were grown in water only. Then, the root tips obtained, were fixed with carnoy's fixative $(60 \mathrm{ml}$ ethanol absolute $+30 \mathrm{ml}$ chloroform $+10 \mathrm{ml}$ acetic acid glacial) for 2 hours. Then, preserved in $70 \%$ ethyl alcohol (Puchtler et al., 1968). For microscopic observation the root tips were stained by Feulgen method (Darlington and La Cour, 1976). Homologous areas were chosen on the preparations for cytogenetic examination. The cells were counted in selected areas, and the number of mitotic cells was also detected. The mitotic index was calculated based on the frequency of division in cell images obtained under a microscope. The preparation was prepared using 5 root tips for each xylol application. Twenty image fields were chosen on these preparations for cytogenetic examination, and chromosome abnormalities were detected. Approximately, 600 cells were evaluated for each application. The occurrence and frequency of chromosomal anomalies in the cells were established by hand counting from the microscope images. Chromosomel anomalies were tried to detected in the cells counted. Preparates were photographed with motorized Leica DM 3000 microscope. For statistical analyses, chromosome anomalies detected in the study were coded as A-G and the concentrations/times of treatment as 1-8 (Table 1-6). Statistical analyses were performed using the Pearson's correlation and analysis of variance method with MINITAB software package.

\section{Results}

It was observed that the different concentrations of xylol treatment on the root tips at different time periods increased mitotic cell division compared to the the control group. Mitotic cell division was observed the highest level at $40 \mathrm{ml} / \mathrm{L}-72 \mathrm{~h}$ treatment. Mitotic cell division was observed high levels at all 72th hours of treatment times according to the 8th hour of treatment times. It was observed that the mitotic index increased in parallel with the increase in concentration with only one exception after $80 \mathrm{ml} / \mathrm{L} \quad$ treatment (Table 1 ).

Table 1. The effect of xylol treatment on mitosis index and chromosome abnormalitiea of Vicia faba root tip meristems.

\begin{tabular}{|c|c|c|c|c|c|c|c|c|c|c|}
\hline & & $\begin{array}{l}\text { Total } \\
\text { counted }\end{array}$ & & & $20 \mathrm{ml} / \mathrm{L}$ & & $40 \mathrm{ml} / \mathrm{L}$ & & $80 \mathrm{ml} / \mathrm{L}$ & \\
\hline & Control & cells & $\begin{array}{l}8 \mathrm{~h} \\
(1)\end{array}$ & $\begin{array}{l}72 \mathrm{~h} \\
(2)\end{array}$ & $\begin{array}{l}8 \mathrm{~h} \\
(3)\end{array}$ & $\begin{array}{l}72 \mathrm{~h} \\
(4)\end{array}$ & $\begin{array}{l}8 \mathrm{~h} \\
(5)\end{array}$ & $\begin{array}{l}72 \mathrm{~h} \\
(6)\end{array}$ & $\begin{array}{l}8 \mathrm{~h} \\
(7)\end{array}$ & $\begin{array}{l}72 \mathrm{~h} \\
(8)\end{array}$ \\
\hline Mitotic indeks (\%) \pm SD & $10 \pm 4.1$ & 600 & $11 \pm 4.1$ & $25 \pm 7.1$ & $12 \pm 6.1$ & $27 \pm 7.3$ & $14 \pm 8.5$ & $30 \pm 7.8$ & $10 \pm 8.4$ & $11 \pm 9.1$ \\
\hline Total anomalies (\%) & 00.00 & 600 & 02.35 & 08.20 & 10.03 & 14.05 & 12.31 & 18.13 & 13.02 & 17.00 \\
\hline $\begin{array}{l}\text { Number of different } \\
\text { anomalies }\end{array}$ & 00.00 & 600 & 3 & 5 & 3 & 5 & 4 & 6 & 3 & 2 \\
\hline
\end{tabular}

S.D.- Standart Deviation Time (h): hour

Some chromosome anomalies were caused by xylol on the root tips of $V$. faba such as bridge chromosome, fish bone chromosome, sticky chromosome, ring chromosome, scattered anaphase, C- chromosome at different stages of mitotic division as shown in (Figures 1-7). The percentage of anomaly was highest after (40 ml/L -72h). Bridge, fish bone, sticky and ring chromosomes were the common types of anomalies in percentage after all treatments. The most frequently observed anomaly was bridge chromosome in all treatments. Treatment with $40 \mathrm{ml} / \mathrm{L}-8 \mathrm{~h}$ mainly induced the highest percentage of chromosome anomalies, chromosome bridge (3\%) and highest percentage of sticky chromosome (2.9\%). The highest percentage of fish bone chromosome anomaly (2.50\%) was observed after (80 ml / L -72h) treatment. Ring chromosome was recorded after all treatments except (80 $\mathrm{ml} / \mathrm{L}-8 \mathrm{~h})$ and $(80 \mathrm{ml} / \mathrm{L}-72 \mathrm{~h})$. C- chromosome anomaly was observed in only 4 treatment (Table 2). The lowest total percentage of different chromosome anomalies were observed at $(80 \mathrm{ml} / \mathrm{L}-72 \mathrm{~h})$ treatment. When all treatments were considered, the most common type anomaly was the fish bone chromosome.

The results of statistical analysis were obtained based on the Pearson's correlation and analysis of variance method. According to the statistical results, there is a considerable positive relation between the treatment concentrations and the percentage chromosome anomaly except after (80 ml/L -72h) treatment (Table 2, Figures 17). Statistical analysis based on Pearson's correlation pointed to the important correlations among the anomaly's types (A-E, A-G, D-F, E-F and F-G) (Table 3). Also, the variance statistical analysis pointed to the important correlations among (A-G, D-F, E-F and F-G) at levels of 0.01 and 0.05 (Table 5). It was shown that the correlations between the treatment time and concentrations in Table (4) are based on the Pearson's correlation method, while the correlations in Table (6) are based on the analysis of variance method. The collected data revealed that there are highly significant correlations among the following (2-3; $2-4 ; \quad 2-5 ; 2-7 ; 3-4 ; 3-5 ; 4-5) \quad$ concentrations /times of treatment at levels of 0.01 and 0.05 (Table 4 and 6). 
Table 2. The percentage of chromosome anomalies in Vicia faba root - tip meristems after treatment with xylol.

\begin{tabular}{|c|c|c|c|c|c|c|c|c|c|}
\hline \multirow{4}{*}{ Chromosome anomaly's type } & & \multicolumn{8}{|c|}{ Xylol concentation/time of treatment } \\
\hline & & \multicolumn{2}{|l|}{$5 \mathrm{ml} / \mathrm{L}$} & \multicolumn{2}{|c|}{$20 \mathrm{ml} / \mathrm{L}$} & \multicolumn{2}{|c|}{$40 \mathrm{ml} / \mathrm{L}$} & \multicolumn{2}{|c|}{$80 \mathrm{ml} / \mathrm{L}$} \\
\hline & & $8 \mathrm{~h}$ & $72 \mathrm{~h}$ & $8 \mathrm{~h}$ & $72 \mathrm{~h}$ & $8 \mathrm{~h}$ & $72 \mathrm{~h}$ & $8 \mathrm{~h}$ & $72 \mathrm{~h}$ \\
\hline & & (1) & $(2)$ & (3) & (4) & (5) & (6) & (7) & (8) \\
\hline Bridge chromosome & A & 1.10 & 1.50 & 1.60 & 2.10 & 3.00 & 2.50 & 0.10 & 0.20 \\
\hline Fish bone chromosome & $\mathrm{B}$ & 1.30 & 1.20 & 1.30 & 1.90 & 1.70 & 1.80 & 1.40 & 2.50 \\
\hline Sticky chromosome & $\mathrm{C}$ & 1.90 & 0.70 & 1.20 & 1.60 & 2.90 & 1.10 & 1.80 & 0.80 \\
\hline Ring chromosome & $\mathrm{D}$ & 0.50 & 0.24 & 1.10 & 1.20 & 1.70 & 2.10 & 2.00 & 1.10 \\
\hline Chromosome breaking & $\mathrm{E}$ & 0.70 & 1.00 & 1.30 & 1.80 & 2.10 & 1.20 & 0.00 & 0.00 \\
\hline Scattered anaphase & $\mathrm{F}$ & 1.10 & 0.00 & 1.00 & 0.80 & 1.15 & 0.50 & 0.00 & 0.00 \\
\hline C- chromosome & G & 0.00 & 0.00 & 0.00 & 0.80 & 0.50 & 0.50 & 0.00 & 0.80 \\
\hline
\end{tabular}

Treatment time (h): hour; Abbreviations: A-G: Codes of chromosome anomalies; Abbreviations: 1-8: Codes of Treatment (5 ml/L -8h): 1, (5 ml/L -72h): 2, (20 ml/L -8h): 3, (20 ml/L -72h): 4, (40 ml/L -8h): 5, (40 ml/L -72h): 6, (80 ml/L -8h):7, (80 ml/L -72h):8.

Table 3. Pearson's correlation based on chromosome anomalies.

\begin{tabular}{|c|c|c|c|c|c|c|}
\hline & $\mathrm{A}$ & $\mathrm{B}$ & $\mathrm{C}$ & $\mathrm{D}$ & $\mathrm{E}$ & $\mathrm{F}$ \\
\hline $\mathrm{B}$ & $0,0870,837$ & & & & & \\
\hline \multirow[t]{2}{*}{$\mathrm{C}$} & 0,398 & 0,142 & & & & \\
\hline & 0,328 & 0,737 & & & & \\
\hline \multirow[t]{2}{*}{$\mathrm{D}$} & 0,192 & 0,292 & 0,349 & & & \\
\hline & 0,648 & 0,483 & 0,397 & & & \\
\hline \multirow[t]{2}{*}{$\mathrm{E}$} & 0,942 & 0,133 & 0,453 & 0,060 & & \\
\hline & $0,001 * *$ & 0,753 & 0,259 & 0,888 & & \\
\hline \multirow[t]{2}{*}{$\mathrm{F}$} & 0,624 & 0,223 & 0,635 & $0,018 * *$ & 0,700 & \\
\hline & 0,099 & 0,595 & 0,090 & 0,967 & $0,050 *$ & \\
\hline \multirow[t]{2}{*}{ G } & 0,702 & 0,397 & 0,331 & 0,411 & 0,705 & 0,349 \\
\hline & $0,048 *$ & 0,330 & 0,423 & 0,312 & $0,041^{*}$ & 0,397 \\
\hline
\end{tabular}

* Significant at the level of $P<0.05$. ** Significant at the level of $P<0.01$. Abbreviations: A-G : Codes of chromosome anomalies Table 4. Pearson's correlation based on treatment (concentration / time).

\begin{tabular}{|c|c|c|c|c|c|c|c|}
\hline & 1 & 2 & 3 & 4 & 5 & 6 & 7 \\
\hline \multirow[t]{2}{*}{2} & 0,446 & & & & & & \\
\hline & 0,316 & & & & & & \\
\hline \multirow[t]{2}{*}{3} & 0,650 & 0,760 & & & & & \\
\hline & 0,114 & $0,048 *$ & & & & & \\
\hline \multirow[t]{2}{*}{4} & $0,4850,269$ & $0,9850,010^{* *}$ & 0,795 & & & & \\
\hline & & & $0,033^{*}$ & & & & \\
\hline \multirow[t]{2}{*}{5} & 0,698 0,081 & $0,7480,050 *$ & $0,8240,023 *$ & 0,805 & & & \\
\hline & & & & $0,029 *$ & & & \\
\hline 6 & $0,1650,724$ & 0,698 0,081 & $0,6920,085$ & $0,7220,067$ & $0,6170,140$ & & \\
\hline \multirow[t]{2}{*}{7} & 0,395 & $0,010 * *$ & 0,229 & 0,142 & 0,280 & 0,368 & \\
\hline & 0,381 & 0,984 & 0,621 & 0,761 & 0,542 & 0,417 & \\
\hline \multirow[t]{2}{*}{8} & 0,337 & 0,308 & 0,261 & 0,350 & 0,071 & $0,4090,363$ & 0,706 \\
\hline & 0,460 & 0,501 & 0,572 & 0,442 & 0,879 & & 0,076 \\
\hline
\end{tabular}

* Significant at the level of $P<0.05$. ** Significant at the level of $P<0.01$ Abbreviations: 1-8: Codes of Treatment

Table 5. Correlation between the investigated chromosome anomalies (Analysis of Variance).

\begin{tabular}{lllll}
\hline & MS & F-value & Probability & Significance \\
\hline A-B & 0.057 & 0.05 & 0.837 & NS \\
A-G & 3.66 & 5.83 & 0.052 & $*$ \\
C-G & 0.38 & 0.74 & 0.423 & NS \\
D-F & 3.15 & 6.22 & 0.010 & $* *$ \\
D-G & 0.52 & 1.22 & 0.312 & NS \\
E-F & 1.97 & 5.78 & 0.050 & $*$ \\
E-G & 2.01 & 5.95 & 0.049 & $*$ \\
\hline MS: Mean Square & $* P<.05$ & $* * P<.01$ & A-G: Codes anomalies & NS: Not Significant \\
\hline
\end{tabular}


Table 6. Correlation between treatment time and concentrations (Analysis of Variance).

\begin{tabular}{|c|c|c|c|c|}
\hline & MS & F-value & Probability & Significance \\
\hline $1-4$ & 0.522 & 1.54 & 0.269 & NS \\
\hline $1-3$ & 0.346 & 0.92 & 0.381 & NS \\
\hline $1-8$ & 0.251 & 0.64 & 0.460 & NS \\
\hline $2-3$ & 1.232 & 6.83 & 0.048 & $*$ \\
\hline $2-4$ & 2.071 & 7.47 & 0.010 & $* *$ \\
\hline $2-5$ & 1.196 & 6.37 & 0.050 & $*$ \\
\hline $2-7$ & 1.067 & 4.87 & 0.045 & $*$ \\
\hline $3-4$ & 0.969 & 8.59 & 0.033 & $*$ \\
\hline $3-5$ & 1.039 & 10.54 & 0.023 & $*$ \\
\hline $4-5$ & 1.086 & 9.20 & 0.029 & $*$ \\
\hline $4-7$ & 0.033 & 0.10 & 0.761 & NS \\
\hline MS: Mean Square & & ns: $1-8:($ & NS: Not Sig & \\
\hline
\end{tabular}
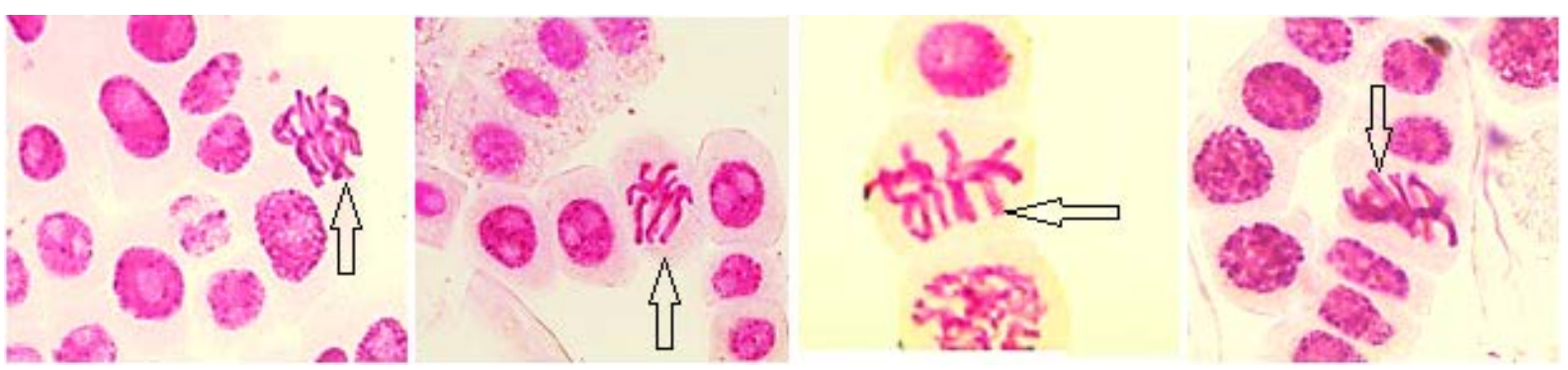

Figure 1. Metaphase stages with fish bone chromosomes after treatment with $80 \mathrm{ml} / \mathrm{L}$ concentration xylol for 8 and 72 hours.

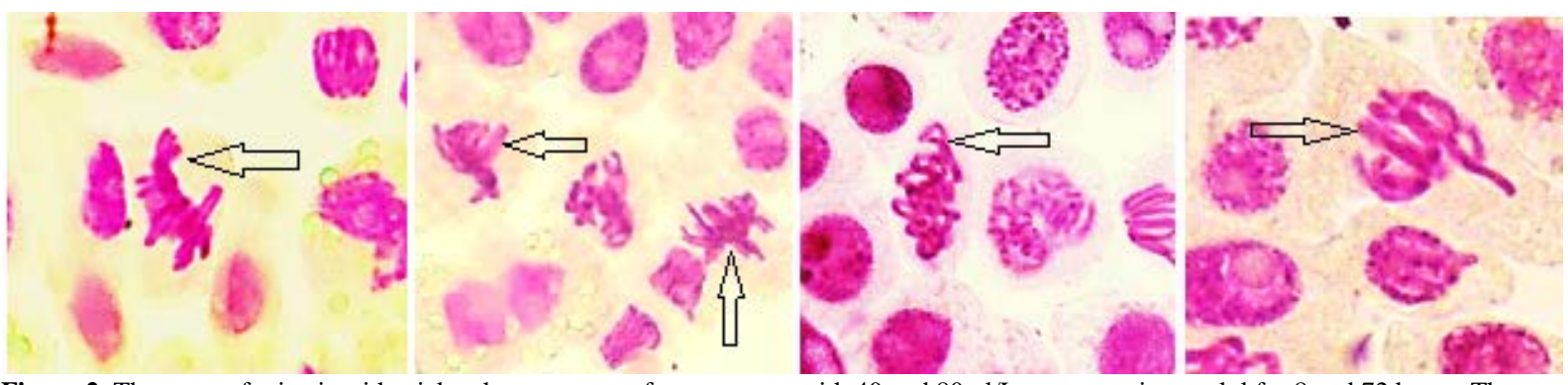

Figure 2. The stage of mitosis with sticky chromosomes after treatment with 40 and $80 \mathrm{ml} / \mathrm{L}$ concentrations xylol for 8 and 72 hours. The first image shows that ever stickiness at late metaphase stage preventing it from entry to anaphase. The third image shows stickiness at prophase stage, the other two images represent metaphases.

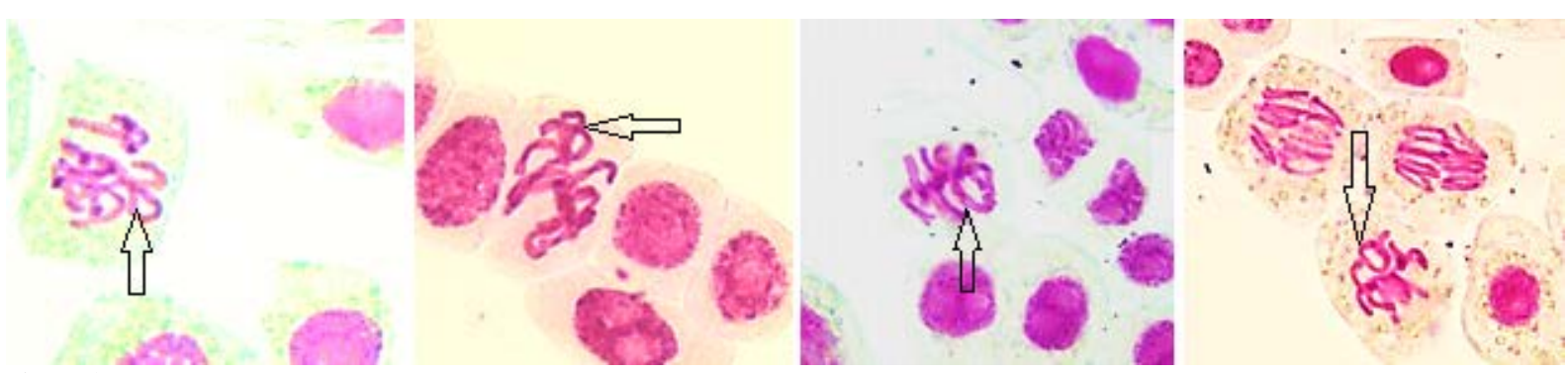

Figure 3. Metaphase stages with ring chromosomes after treatment with $40 \mathrm{ml} / \mathrm{L}$ concentration xylol for 8 and 72 hours.
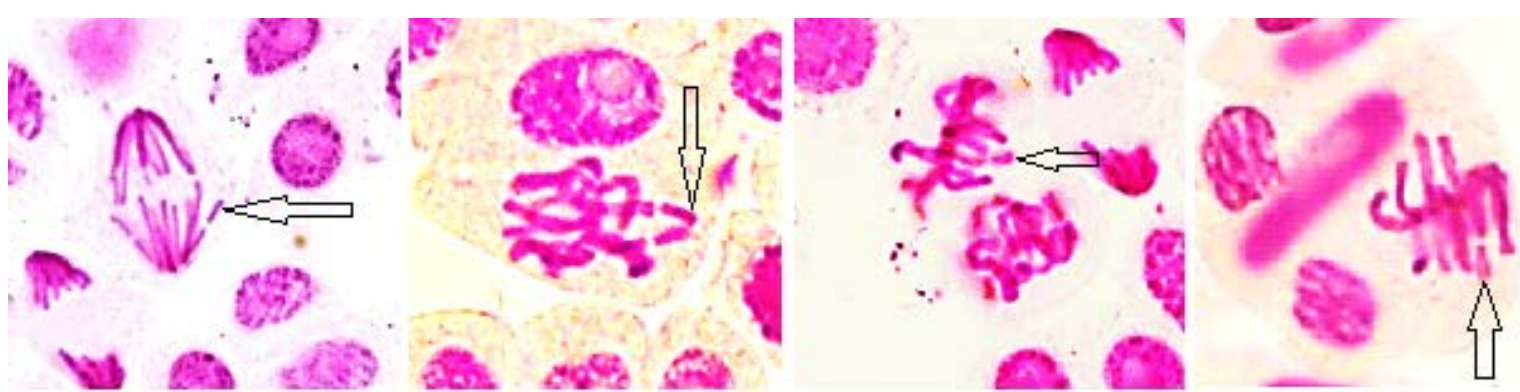

Figure 4. The stage of mitosis with chromosome breaking after treatment with $40 \mathrm{ml} / \mathrm{L}$ concentration xylol for 8 and 72 hours. First image: anaphase stage, the other three images represent metaphases. 

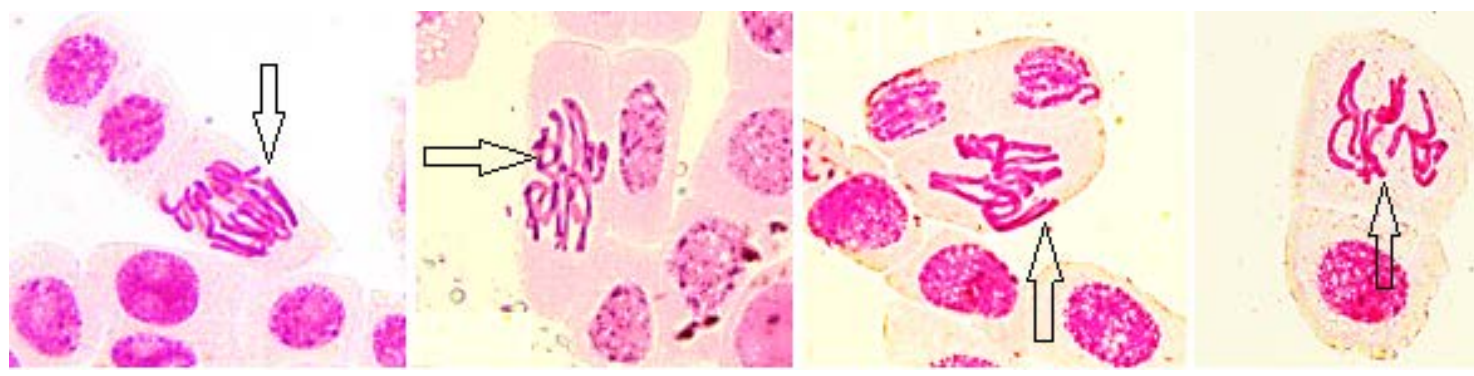

Figure 5. The first and fourth images anaphase stage with scattered anaphase chromosomes after treatment with $40 \mathrm{ml} / \mathrm{L}$ concentration xylol for 8 hour, the other two images represent meta-phase with fish bone chromosomes after treatment with $40 \mathrm{ml} / \mathrm{L}$ concentration xylol for 8 hours.
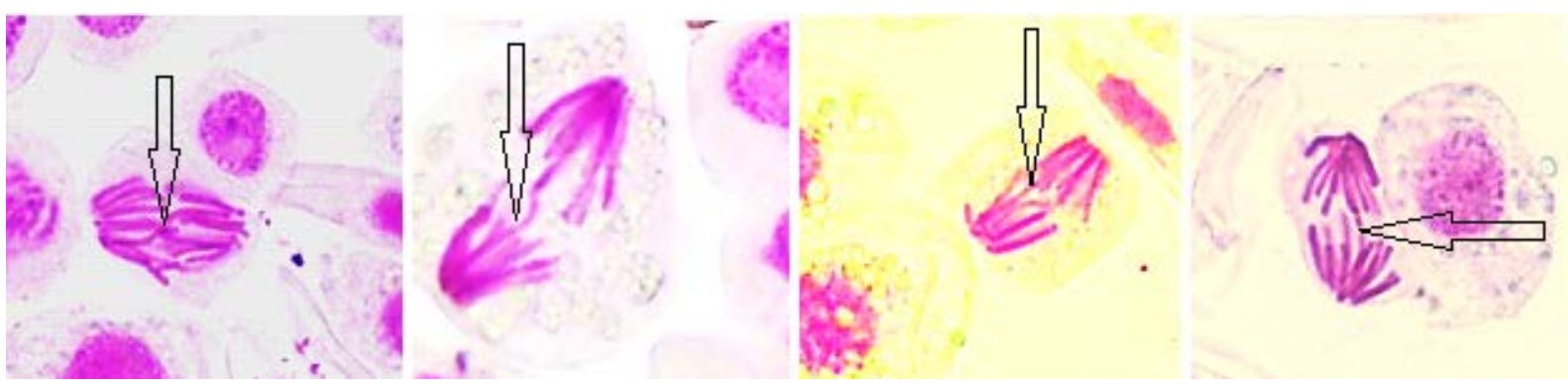

Figure 6. Anaphase stage with anaphase bridges after treatment with $40 \mathrm{ml} / \mathrm{L}$ concentrations xylol for 8 and 72 hours.
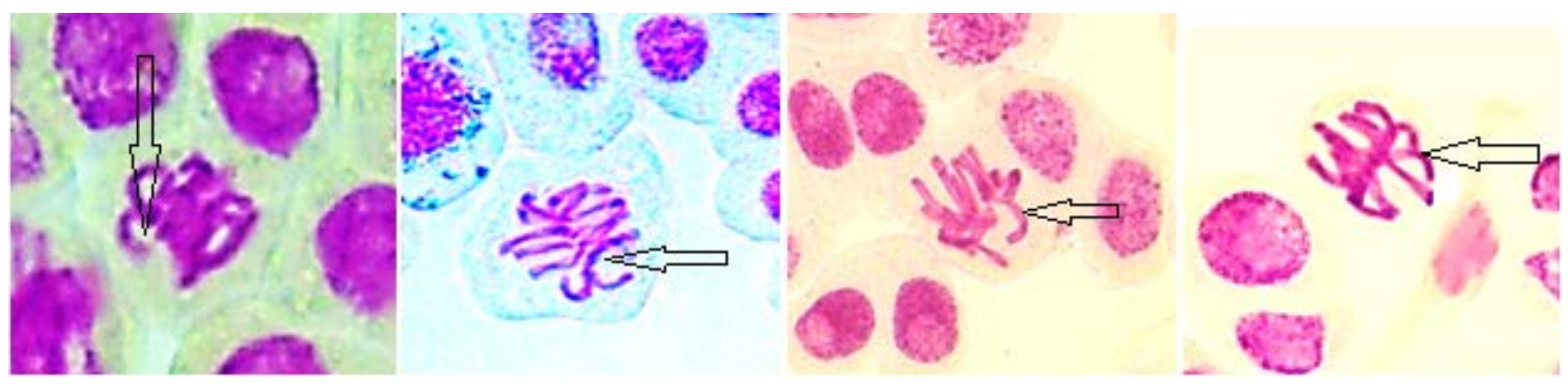

Figure 7. Metaphase stage with chromosome $C$ after treatment with 40 and $80 \mathrm{ml} / \mathrm{L}$ concentrations xylol for 8 and 72 hours.

\section{Discussion}

In the current study, cytogenetic effects of xylol on meristematic cells of root tips belonging to $V$. faba (widely used as food by humans) have been investigated. We determined that xylol stress affects mitotic cell division and causes various types of chromosome anomalies. The obtained results of chromosome anomalies were mostly on the same track with (Alaca et.al., 2020) after treatment the Vicia faba seeds with xylol in different concentrations (10 and $100 \mathrm{ml} / \mathrm{L}$ ) for different times (12 and 24 hours) of treatment. Similarly, Barbhuiya et al. (2018) investigated the effect of benzene and thinner solvents, which are used as materials in many industrial products as in the case of xylol, on the root tip cells of Allium cepa. They observed that the solvents enhanced the mitosis index and caused chromosomal anomalies. Similar to our results, they observed that the solvents caused abnormalities such as bridge, sticky and scattered chromosomes and increased the mitosis index.

In another study, it has been determined that the chromosome adherence and the bridge chromosomes were the most frequently observed anomalies in cells of lettuce after exposure to glyphosate (Silva et al., 2018). In our study, the mitotic division of the root tip treated with xylol gradually increased in comparison to the control group except to $80 \mathrm{ml} / \mathrm{L}$ treatment. Parween et al., (2011) obtained similar results examining the effect of cadmium chloride in pure germ line in broad beans ( $V$. faba) in relation to chromosome anomalies and cell division rate. However, in another study, the seeds of Lens culinaris Medik.were kept at different concentrations of $\mathrm{Sr}$ (stronsiyum) (0.05, 0.1, 0.25, 0.5 and $1.0 \mathrm{M}$ ) for 12 hours; those anomalies showed no regular distribution (Sepet and Çanl1, 2020). Thus, it is not in agreement with the previous reference and our work.

As an example of similar results with non-solvent treatment, we refer to Özdemir et al., (2008), where the effects of uranium exposure on $V$. faba cells are investigated. They found a concentration dependent increase in mitotic index.

The statistical analysis therein was also performed using the Pearson's correlation and analysis of variance method. The results were taken into account in the significance evaluations at $P<0.05$ and $P<0.01$ levels. Similarly, we tried to prove and evaluate the results obtained from laboratory studies numerically. According to the statistical results derived, different concentrations of xylol treatment on root tip increased the mitotic cell division at the different periods of time, compared to the control group. However, mitotic division was decreased at $(80 \mathrm{ml} / \mathrm{L}-72 \mathrm{~h})$ treatment. At the same time, the least number of different anomalies was seen in this application. 
We refer to this concentration with sever damage on the cell cycle and delay the mitotic division. On the contrary, the different anomalies were mainly observed at the application level $(80 \mathrm{ml} / \mathrm{L}-8 \mathrm{~h})$, where the mitosis was at its highest frequency. This result shows that the concentration and the time periods of the treatment in mitotic division is important. As shown in the tables 3-6 according to Pearson's correlation and analysis of variance method, it has been found that there have been statistically important differences at levels of $0.01 \mathrm{P}$ between ring chromosome and scattered anaphase. At the same time, there have been statistically important differences at levels of $0.05 \mathrm{P}$ between chromosome breaking and Cchromosome (Tables 3,5). We can say that these chromosomal anomalies are inter-related and trigger each other. Studies on the effect of xylol on chromosomes in the literature have mostly been done on animal cells. Donner et al., (1980) exposed rats to technical grade xylol by inhalation at $300 \mathrm{ppm}, 6 \mathrm{~h} /$ day, 5 days/week for up to 18 weeks. The chromosome damage has been detected in animals examined after 9, 14 or 18 weeks exposure. Thus, these researchers stated that that xylol administered to rats for different periods of time, similar to our findings, caused chromosomal abnormalities in the cells. Lebowitz et al. (1979) observed the damage of chromosome in bone marrow cells of rats after dosing with xylol.

We think that, based on our finding results, xylol as an ingredient in many industrial products such as farming products should be reconsidered as it caused sever anomalies in chromosomes for various concentrations $(5,20,40$ and $80 \mathrm{ml} / \mathrm{L})$ and different treatment durations (8 and $72 \mathrm{~h}$ ), which may cause plant growth disorder and deformations.

\section{References}

Alaca C, Özdemir A, Bozdağ B and Özdemir C. 2020 Cytogenetic effects of $\mathrm{C}_{6} \mathrm{H}_{4}\left(\mathrm{CH}_{3}\right)_{2}$ (xylol) on meristematic cells of root tips of Vicia faba L. and mathematical analysis. Caryologia 73: 27-35.

Barbhuiya SN, Barhoi D, Datta S.K, and Giri1 S. 2018. Two Major Components of Steel Fabrication Industry, Benzene and Thinner Induce Cytotoxicity in Allium cepa L. Root Cells. Cytologia 83(2): 155-158.

Barchan A, Bakkali M, Arakrak A, Pagán R and Laglaoui A. 2014. The effects of solvents polaritiy on the phenolic contents and antioxidant activity of three Mentha species extracts. Int $J$ Curr Microbiol App Sci. 3(11):399-412.

Cahours A. 1850. Recherches sur les huiles légéres obtenues dans la distillation du bois. Compte rendus 3: 319-323.

Darlington CD and La Cour L.F. 1976. The handling of chromosomes, Sixth Edition, George Allen and Unwin Ltd., London, 0-04-574014-3.
Donner M, Maki-Paakkanen J, Norppa H, Sorsa M and Vainio H. 1980. Genetic toxicology of xylols. Mutat Res 74:171-172.

Fabri J, Graeser U and Simo T. 2000. "Xylols". Ullmann's Encyclopedia of Industrial Chemistry. doi:10.1002/14356007.a28_433. ISBN 978-3527306732.

Ghasemzadeh A, Jaafar HZ and Rahmat A. 2011. Effects of solvent type on phenolics and flavonoids content and antioxidant activities in two varieties of young ginger (Zingiber officinale Roscoe) extracts. J Med Plants Res. 5(7):1147-1154.

Jenifer M. 1994. Xylol: Its toxicity, measurement of exposure levels, absorption, metabolism and clearance, Journal Pathology 26: 301-309.

Lebowitz H, Brusick D, Matheson D, Jagannath DR, Reed M, Goode S and Roy G. 1979. Commonly used fuels and solvents evaluated in a battery of short-term bioassays, Environmental Mutagen 1: 172-173.

Osama H, Elhamalawy and Aida I. El Makawy. 2020. Estimation of Grape Seed Oil Alleviative Role on Cadmium Toxicity in Male Mice. Jordan Journal of Biological Sciences 13: 77 - 83.

Özdemir A, Bozdağ B, Sepet H, Parlak Y, Kocabaş O, Serap E and Özdemir C. 2015. Cytogenetic effects of technetium on meristematic cells of root tips of Vicia faba L. and statistical comparison. Caryologia 68: 200-206.

Özdemir C, Ereeş S and Çam S. 2008. Cytogenetic Effects of Uranium On Root Tip Cells Of Vicia faba L. Botanica Lithuanica 14: $155-158$.

Parween T, Jan S, Mahmooduzzafar MP, Mujib A and Fatma T. 2011. Genotoxic impact of cadmium on root meristem of Vicia faba L. Russ Agric Sci. 37: 115-119.

Puchtler H, Sweat Waldrop F, Conner HM and Terry MS. 1968. Carnoy fixation: practical and theoretical considerations. Histochemie 16: 361-371.

Shraideh ZA. 2010. Toxicity of triethyllead chloride (TriEL) on cytoplasmic shuttle streaming, structure, growth and migration of the plasmodial slime mold Physarum polycephalum, Jordan Journal of Biological Sciences, 3: 33 - 40.

Sepet H and Çanlı M. 2020. Concentration- and time-dependent effects of strontium on Lens culinaris Medik. Botanica Serbica 44: $175-182$

Silva AC, Gonçalves CG, Scarano MC, Pereira MR and Martins R. 2018. Effect of glyphosate on guineagrass submitted to different soil waterpotential. Planta Daninha 36:1-12.

Şutan NA, Uta G and Barbucean D. 2018. Oxidative stress and cytogenetic effects in root tip cells of Allium cepa L. induced by alcoholic extracts of Leptinotarsa decemlineata (Say). Caryologia 71: 1-9.

Tengjaroenkul B and Neeratanaphan L. 2020. Acute Effect of Cadmium Chloride on Chromosomal Abnormalities in the Nile Tilapia Fish In Vivo, Jordan Journal of Biological Sciences, 13: $127-132$

Vijayakumar Y, Ganesh KM, Ramana MV and Bosco BR. 2015. Nanostructured flower like V2O5 thin films and its room temperature sensing characteristics. Ceramics International 41: 2221-2227. 